\title{
Teorija objektnih odnosa i njezine implikacije $u$ pastoralnoj psihologiji i psihologiji religije
}

\author{
Antun Volenik* \\ a.volenik@ffrz.hr \\ https://orcid.org/0000-0002-1017-3218 \\ Irma Džambo** \\ irmadzambo@yahoo.com \\ https://orcid.org/0000-0002-1536-9666
}

https://doi.org/10.31192/np.19.3.1

UDK: $159.964 .2: 2-184.3$

2-46:159.964.2

Pregledni članak / Review

Primljeno: 6. travnja 2021.

Prihvaćeno: 8. lipnja 2021.

Rad se bavi odnosom teorije objektnih odnosa kao dijelom psihoanalitičke $i$ psihodinamske psihologije te religije/duhovnosti u širem smislu. Također nastoji pokazati zaokret u valoriziranju religije koji je teorija objektnih odnosa, a osobito Winicottova teorija pravog i lažnog ja te prijenosnog objekta, donijela u psihodinamskoj paradigmi. Rad prikazuje Freudov, Jungov $i$ Adlerov odnos $i$ stav prema religiji i duhovnosti.

Ključne riječi: psihoanalitička i psihodinamska psihologija i psihoterapija, psihologija religije, teorija objektnih odnosa $i$ religioznost/duhovnost.

\section{Uvod}

Na našem je jezičnom području malo pokušaja bavljenja odnosa psihodinamske psihologije i psihoterapije i pastoralne psihologije. ${ }^{1}$ Ovaj rad želi nadopuniti tu prazninu obrađujući ovaj problem sa stajališta psihologije religije budući da se u radu usredotočujemo upravo na religijske i duhovne fenomene

\footnotetext{
* Doc. dr. sc. Antun Volenik, Sveučilište u Zagrebu, Fakultet filozofije i religijskih znanosti, Jordanovac 110, HR-10000 Zagreb.

***Doc. dr. sc. Irma Džambo, JU Dom zdravlja Kantona Sarajevo, Igmanska 52, BiH-71101 Sarajevo.

${ }^{1}$ Možemo izdvojiti: Willim KEILBACH, Psihologija religije, psihologija dubina i pastoralna psihologija, Bogoslovska smotra, 37 (1967) 1-2, 11-24. Ranije, Keilbach piše dva članka o Adlerovoj individualnoj psihologiji i Freudovoj psihoanalizi. Vidi još: Šimun Š. ĆORIĆ, Psihologija religioznosti, Jastrebarsko, Slap, 1998; Mihály SZENTMÁRTONI, Osjetljivost za čovjeka, Zagreb, Glas Koncila, 2009; Mihalj SZENTMARTONI, Religiozni simboli u psihologiji C. G. Junga, Obnovljeni život, 36 (1981) 5, 434-436.
} 
kao moguće čimbenike otpornosti koji pomažu ego snagama u tijeku psihoterapeutskog procesa i pastoralnog savjetovanja. Budući da psihodinamska psihoterapija ${ }^{2}$ i teoretska psihološka podloga obuhvaćaju sve škole u pravce koji uključuju pojam nesvjesnog, transfera i kontratransfera, te shvaćaju ličnost više ili manje oslonjeni na Freudovu psihoseksualnu teoriju razvoja ličnosti, ovdje ćemo se šire pozabaviti Freudovom teorijom i psihoanalizom u užem smislu, ego i self psihologijom, te osobito teorijom objektnih odnosa uz Jungovu analitičku i Adlerovu individualnu psihologiju te odnosom svake od tih škola prema religiji i religioznom.

\section{Freudova psihoanaliza}

Stereotipno se Freuda doživljava kao onoga tko se s religijom i religioznim/ duhovnim u čovjeku obračunao jednom za svagda no Freud se zapravo cijelog života bavio religijom i religioznim. ${ }^{3}$ Njegov pristup religiji uvelike je obilježen pozitivizmom koji ga usmjerava na racionalizam i antireligijsko razmišljanje, kako možemo čitati u većini njegovih djela o ovoj temi. ${ }^{4}$ Ipak, on religiju - zajedno s umjetnošću, filozofijom i etikom - svrstava u najviša ostvarenja ljudske civilizacije, ali to tvrdi u kontekstu dokazivanja da ta ista religija počiva na infantilnim iluzijama i projekcijama, ${ }^{5}$ što nalazimo i u Freudovoj studiji slučaja Čovjek vuk. ${ }^{6}$ Ovdje nalazimo i sljedeću rečenicu:

${ }^{2}$ Iako se pojmovi psihodinamsko i psihoanalitičko koriste gotovo kao sinonimi, njihova najuočljivija razlika jest upravo na području psihoterapije. Ipak, ta dva pojma puno su šira i danas se uobičajeno govori od četiri psihoanalitičke psihologije: psihologija nagona, ego i self psihologija te psihologija objektnih odnosa s tim da se predstavnici zadnjih triju ne mogu uvijek svrstati $\mathrm{u}$ kategoriju psihoanalitičke psihologije te ulaze u puno širi krug psihodinamike. Taj krug je još širi kada se tu ubroji sve koji respektiraju psihoanalitičku teoriju ličnosti i polaze od nekih njezinih zasada kao što su nesvjesno ili pak transfer i kontratransfer (dubinska psihologija), ali su zapravo stvorili vlastiti teoretski koncept ili moderne integrativne pravce.

${ }^{3}$ Usp. Paul C. VITZ, Sigumund Freud's Christian Unconscious, New York, Gracewing Publishing, 1988; vidi još: Paul C. VITZ, Psihologija kao religija. Kult samoobožavanja, Split, Verbum, 2011.

4 Počinje 1904. zapažanjem o vlastitoj omaški kad mu umjesto »Stvori Bog čovjeka na svoju sliku« na pamet dolaze riječi »Stvori čovjek Boga na svoju« te dodaje: »Interesantno je da se kao zamjena pojavila rečenica u kojoj Božanstvo biva degradirano na status ljudskoga pronalaska.« Sigumund FREUD, Odabrana dela Sigmunda Frojda. Psihopatologija svakodnevnnog života, Novi Sad, Matica srpska 1979/1904, 5.

${ }^{5}$ Sigumund FREUD, Budućnost jedne iluzije, Zagreb, Naprijed, 1927/1986.

${ }^{6}$ Usp. Muriel GARDINER, O Čovjeku vuku, Zagreb, Naprijed, 1971/1918. U njoj je uklopljena Freudova studija slučaja pacijenta S. Pankjeffa kojeg je on nazvao Čovjek vuk (u Freudovim sabranim djelima naslovljena Aus die Geschichte einer infantilen Neurose). Tu je autobiografiju samog Pankjeffa, njegova doživljaja Freuda, prikaz kasnijeg života i terapije koju je imao s R. Brunswick, uz predgovor A. Freud koja izrijekom navodi da ovu knjigu smatra jedinstvenom longitudinalnom studijom jednog ranog Freudova pacijenta, što joj daje posebno mjesto među 
»Zanemarimo li patološke fenomene možemo reći da je religija u našem slučaju postigla ono za što se je i uvodi u pojedinčev odgoj. Ona mu je sputala seksualne težnje time što mu je ponudila stanovitu sublimaciju i čvrsto sidrište, obezvrijedila mu obiteljske odnose i time ga obranila od prijetnje izolacijom, i to tako što mu je omogućila da se priključi velikoj zajednici ljudi. Dalje, zaplašeno dijete postalo je društveno, uljudno i podatno odgoju. $\ll^{7}$

No već i ovdje Freud upućuje svoje čitatelje na Totem i tabu u smislu kritike religije. Kada, uz to, uzmemo i ostala dva važna djela o ovoj temi, naime Povijest jedne iluzije te Mojsije $i$ monoteizam, ${ }^{8}$ sa svime što znamo iz Freudove biografije, kao i podatci koje nalazimo u studiji slučaja Čovjek vuk, nalazimo iznijansiraniju, ali i dalje oštru kritiku religije, osobito one monoteističke. Zato Freud predlaže sljedeće:

»Odvraćanjem svojih očekivanja od onostranog, i usmjeravanjem svih oslobođenih snaga na zemaljski život, vjerojatno će moći postići to da život svima postane podnošljiv i da kultura više nikoga ne tlači. Tad će on bez razmišljanja moći, s jednim našim drugom u nevjeri, reći: 'Nebo prepuštamo anđelima i vrapcima'.«9

Uz to objavljuje i članak o religiji pod naslovom Prisilne radnje $i$ religiozne radnje gdje nalazimo duboku analogiju između prisilnih radnji i vjerskih ceremonija s hipotezom da se prisilna neuroza može smatrati privatnom religijom, a religija javnom prisilnom neurozom. Razlika između neuroze i religije je samo $\mathrm{u}$ tome što je pokretač neuroze potisnuti seksualni nagon, a religije potisnuti ja-nagon.

Stvarajući svoju kritiku religije Freudove ideje gotovo istovremeno nailaze na kritiku, i to ne samo od strane »disidenata« kao što su bili A. Adler i C. G. Jung ili istaknutih mislilaca kao što je bio M. Buber, ${ }^{10}$ već i od »lojalnih « psihoanalitičara kao što je bio švicarski pastor O. Pfister. On objavljuje Iluziju budućnosti u kojoj pokazuje da Freudova kritika religije počiva na njegovu vlastitom

drugim Freudovima studijama slučaja - Anne O (1895), Dore (1905), Malog Ivice (1909) ili Čovjeka štakora (1909).

7 Isto, 26.

${ }^{8}$ Osnovne ideje u ovim Freudovim djelima poznate su: monoteizam je utemeljen na edipalnom kompleksu koji Freud izvlači iz ubojstva oca udruženih sinova; kršćanstvo i ideja Boga Oca kao infantilni transfer koji izlazi iz djetetove tjeskobe koja se rađa zbog potpune ovisnosti o ocu i koji ostaje i u odraslom čovjeku, (npr. tjeskoba od neizbježne smrti; judaizam kao Mojsijev »izum« itd.)

9 Sigumund FREUD, Budućnost jedne iluzije, Zagreb, Naprijed, 1927/1986, 35.

${ }^{10}$ Buberovo djelo Mojsije svojevrstan je hebrejsko-teološki odgovor na Freudovu knjigu Mojsije $i$ monoteizam u kojoj pokušava, između ostaloga, dokazati povijesnost Mojsijeve osobe $\mathrm{i}$ njegova jedinstvenog odnosa s Bogom (usp. Martin BUBER, Moses. The Revelation And The Covenan, Kindle edition, Muriwai books, 1946/2018). 
gotovo religijskom vjerovanju u budućnost i trijumf racionalističke znanosti, a to bi, po Freudovom vlastitom konceptu vjere, bila iluzija. ${ }^{11}$

Zaključno, ovdje možemo reći da je Freudovo shvaćanje religije bilo redukcionističko, utemeljeno na njegovim filozofskim uvjerenjima koja su religiju promatrale samo kao iracionalnu i prolaznu fazu razvitku prema realističkom, realnom i znanstvenom stupnju čovječanstva. Po nekim autorima ${ }^{12}$ to je i osnovni problem Freudova odnosa prema religiji i njegove analize religije. Izašavši iz kliničke analize, što je bilo njegovo područje (gdje je, kako smo vidjeli, uspijevao inkorporirati religijska uvjerenja i procese u dinamiku osobnog razvoja i terapije) on se upustio $u$ avanturu filozofskog razjašnjenja religije $u$ cjelini, sugerirajući u svojim djelima da je upravo psihoanaliza put rasvjetljenja i kraja religije kao iluzije. To naravno stoji u direktnoj opreci s njegovim, više puta ponovljenim, stavom da psihoanaliza nije univerzalna i svjetska, a niti čak ni kompletna antropologija. ${ }^{13}$ Ipak, sve to nije spriječilo brojne neofreudovce da pišu i istražuju religijsku problematiku u toj domeni što možemo pratiti u povijesnom razvoju psihodinamske psihologije i psihoterapije.

\section{Adlerova individualna psihologija}

Adler razvija novu školu koju naziva individualna psihologija u kojoj se čovjeku i njegovim psihičkim problemima pristupa s integrativno-holističke perspektive, naglašavajući socijalni kontekst u kojem se on razvija i živi. Naglašava da osobnost, kao cjelovito i nedjeljivo jedinstvo vođeno ciljevima (teleološka paradigma), integrira svjesno i nesvjesno u takozvani dinamički konstrukt stila života, važan pokazatelj psihosocijalne kvalitete osobnosti. Koncept Boga kao krajnjeg ljudskog cilja jest ideal prema kojem se teži, pokazujući put koji treba slijediti prema idealnom društvu. Trseći se da se ujedini s Bogom, pojedinac će moći pobijediti stalne osjećaje inferiornosti i nesavršenosti (poznato Adlerovo teoretsko polazište volje za moći), dostižući samodostignuće i korisnost svoga života. Naglašavajući značajnu ulogu religije u društvenom životu, individualna psihologija želi pokazati da je glavna funkcija religije razvijanje osjećaja bliskosti u društvenoj zajednici, doprinoseći tako razvoju čovječanstva. ${ }^{14}$

\footnotetext{
${ }^{11}$ Oscar PFISTER, The Illusion of a Future. A Friendly Disagreement with Prof. Sigmund Freud, International Journal of Psycho-Analysis, 74 (1993) 557-589.

${ }^{12}$ Usp. Antoon VERGOTE, Psychoanalysis, phenomenological antropology and religion, Leuven, Leuven Univeristy Press, 1999.

${ }^{13}$ Sigumund FREUD, New introductory lectures on psych-analysis, u: J. Strachey, The standard edition of the complete psychological works of Sigmund Freud, sv. 22, London, Hogarth Press, 1964/1933.

${ }^{14}$ Usp. Zoltan AMBRUS, Theological aspects of Alfred Adler's individual psychology, European Journal of Science and Theology, 5 (2009) 3, 37-58.
} 
U djelu Individualna psihologija i religija Adler uopće ne diskutira postoje li religiozna pitanja u psihoterapiji ili ne postoje. Polazi od činjenice poznate svakom iskusnom terapeutu svoga vremena da se religiozni problemi pojavljuju u praksi (a riječ je, naravno, o pacijentima početkom dvadesetog stoljeća koji su dobili veće ili manje religiozno obrazovanje u kući i školi).

»Prema tome sasvim je prirodno što se psihoterapeut, kome je cilj ponovno uspostavljanje ravnoteže čitave ličnosti, a ne samo jednog organa, mora interesirati i za takva pitanja svoga pacijenta. $\aleph^{15}$

Adlerovo je odlučno mišljenje da dubinska psihologija ne može i ne smije davati odgovore na pitanja o postanku religije, jer to prelazi njenu nadležnost. »Svakako se znanstveno ne može dokazati da postoji Bog. U njega se naprosto vjeruje. ${ }^{16}$ Dodajmo ovdje da je Adlerov učenik F. Künkel otišao mnogo dalje od Adlera u produbljivanju društvenog značenja religioznosti, osobito u seriji svojih knjiga o karakteru i pokazivanju da religioznost nije neuroza.

\section{Jungova psihologija religije}

Nakon dramatičnog razlaza s Freudom (1912) C. G. Jung ${ }^{17}$ počinje graditi vlastit psihološki pravac koji će kasnije nazvati analitička psihologija. Ovdje izdvajamo proces individualizacije - centralni pojam jungovske teorije ličnosti i stvaranja zrele osobnosti u povezanosti s religijom i njegove radove na području psihologije religije pod kršćanskim vidikom: o Kristu, ${ }^{18}$ misi (1941/42) i Trojstvu (1942), zajedno s Aionom (1951) i odgovorom na Joba (1952). U njima Jung detaljno istražuju i dokazuje važnost kršćanske poruke u procesu indivi-

${ }^{15}$ Vladeta JEROTIĆ, Sabrana dela. Psihoanaliza i religija, Beograd, Zadužbina Vladete Jerotića - IP Ars libri, 2007, 17.

${ }^{16}$ Eenst JAHN, Alfred ADLER, Religion und Individualpsychologie. Eine prinzipielle Auseinandersetzung über Menschenführung, Beč - Leipzig, Passer, 1933, 60, prema Vilim KEILBACH, Individualna psihologija i religija, Obnovljeni život, 19 (1938) 7, 427-436, 430.

${ }^{17}$ Sin švicarskog protestantskog pastora koji je odbacio roditeljsko protestantsko kršćanstvo, ali se cijeli život bavio utjecajem religiozne (prvenstveno kršćanske) misli i prakse na čovjekove psihičke procese. Tome je nadodao zanimanje za istočnjačke religije i vjerovanja kao i specifične oblike spiritizma povezane kako s alkemijom i astrologijom tako i tadašnjim postignućima u fizici i astronomiji.

${ }^{18}$ Tako on kaže: »Simbol Krista od najveće je važnosti za psihologiju ukoliko je, uz lik Bude, možda najviše razvijeniji i diferencirani simbol osobnosti. To zaključujemo iz bogatstva i sadržaja onih izjava koje imamo o Kristu i koje u visokom stupnju odgovaraju psihološkoj fenomenologiji osobnosti, premda ne sadržavaju u sebi sve elemente arhetipa «(Carl G. JUNG, O religiji i kršćanstvu, Đakovo, Plamen, 1996/1956, 32). 
dualizacije. ${ }^{19} \mathrm{Tu}$ koristi pojmove Boga, Marije, Isusa, Duha Svetoga i Sotone i poziva se na velike teme kršćanstva - grijeh, sud, oproštenje, otkupljenje, smrt, uskrsnuće, zlo - da bi ilustrirao svoje psihološke argumente.

\subsection{Proces individualizacije}

Temelji individualizacije postavljaju se u prvoj polovici života i dramatično odvijaju u prijelazu u drugu polovicu života kroz otkrivanje osobnog nesvjesnog, što je put prema kolektivnom nesvjesnom i sistemu arhetipova. ${ }^{20}$ Ovdje smo u stadiju onoga što Jung naziva Persona (pandan lažnom ja/selfu). Ulazak u Sjenku/sjenu prvi je korak pema individualizaciji, to jest uviđanju i prihvaćanju inferiornih i negativnih strana vlastite osobnosti. Sljedeći korak je otkrivanje anime ili animusa, arhetipa koji personificiraju dušu i najdublje unutarnje procese psihe, gdje je Jung puno manje jasan kada govori o ženskom animusu u odnosu na animu kod muškarca. ${ }^{21}$

U toj dinamici samorealizacije ili individuacije završni stadij zavisi podjednako od naših svjesnih aktivnosti kao dopuštanja i prepuštanja arhetipovima Selfa i Boga da nas, kroz psihičko-emotivne procese, vode prema punini. ${ }^{22}$ Ovako gledano, religijski razvoj predstavljao bi upoznavanje naših arhetipova, osobito slike Boga, te naše prihvaćanje tih i njihova integracija u našu osobnost. Jung nadalje smatra da proces integracije svjesnog i nesvjesnog može biti ubrzan tehnikama aktivne imaginacije, gdje se u svjesno dovode nesvjesne slike i simboli. Ta tehnika je slična onom što je koristio još Ignacije Lojola u svojim Duhovnim vježbama, ${ }^{23}$ što će Jung iskoristiti u seriji članaka o toj temi.

\subsection{Važnost religije i religioznih simbola}

Jung pokazuje da je arhetipsku sliku Boga lako otkriti u svim, pa i najprimitivnijim kulturama, odnosno u mitovima i obredima tih kultura. Riječ je, dakle, o općeljudskoj pojavi. Pojam Boga, prema tome, nije plod osobnog iskustva pojedinca, kako je to zamislio Freud, već čovjek pojam Boga nosi nekako utisnut u svoj psihi. Jung time ne želi dokazivati Božju opstojnost, nego jednostavno, analizirajući ljudsku psihu, zaključuje da između onoga što religiozni ljudi nazi-

\footnotetext{
${ }^{19}$ Usp. Nicola STEIN, Jung, Carl Gustav, u: D. LEEMING i dr. (ur.), Encyclopedia of Psychology and religion, New York, Springer Science+Business Media, 2014, 477-480.

${ }^{20}$ Usp. Daniel M. WULFF, Psychology of Religion Classic and Contemporary, New York - Toronto, John Siley and Sons, 1991, 321

${ }^{21}$ Usp. Carl G. JUNG, Psychological Types, Princeton, Princeton University Press, 1921/1971.

${ }^{22}$ Usp. Karl L. BECKER, Unlikely Companions. C. G. Jung on the Spiritual Exercises of Ignatius of Loyola, Leominster, Gracewing, 2001.

${ }^{23}$ Jung se Ignacijem, isusovcima i Duhovnim vježbama bavi još od svoga djetinjstva (strah od jezuita).
} 
vaju Bogom i onoga što postoji u kolektivnom nesvjesnom čovječanstva postoji identičnost. Najviše što bismo mogli ustvrditi jest to da u čovjekovoj psihičkoj strukturi nalazimo neku osnovnu usmjerenost, orijentiranost prema traženju Boga. Zato, u kontekstu cjeline Jungova shvaćanja čovjeka, možemo zapravo reći ono što sugerira sam Jung: između osobne zrelosti i religioznih simbola postoji nutarnja, organska povezanost iz čega slijedi da je svaka (autentična) religioznost ujedno i nosilac osobne zrelosti. I obratno: svaka dezintegracija religioznosti utječe i na psihičku ravnotežu osobe. ${ }^{24} \mathrm{Na}$ taj način on je radikalno prevrednovao ulogu religioznosti u razvoju ličnosti, gdje ona postaje upravo nosilac tog razvoja što je, uz važnost religioznih simbola, njegova centralna zasluga, ne ispuštajući iz vida da mu je kršćanstvo bilo polazište no ne i ishodište.

Jung je prilično marginaliziran u današnjoj psihologiji, ali još uvijek privlači pažnju mnogih istraživača. ${ }^{25}$ Bio je inspiracija self help psihologije, osobito one inspirirane New Ageom, spiritizmom i paganizmom, koji vrlo selektivno koristeći njegovu misao, što bi samom Jungu bilo neprihvatljivo. ${ }^{26}$ Spomenimo i njegovu posrednu ulogu u osnivanju Anonimnih alkoholičara i cijelog pokreta 12 koraka. ${ }^{27}$ Jung je bio na meti kritika i zbog svog mogućeg antisemitizma i neetičnosti u psihoterapeutskom radu (najpoznatija je afera sa S. N. Spielrein). Ipak, Jungove bazne teoretske postavke pomažu u dijalogu između psihologije i različitih religioznih ${ }^{28}$ i duhovnih tradicija. ${ }^{29}$

\section{Ego $i$ self psihologija}

Od važnih imena ego psihologije (A. Freud - Ego i mehanizmi obrane, H. Harmann, D. Rapaport, R. Spitz, M. Maler) za naše istraživanje važan je rad E. Eriksona, ne samo zbog njegovih studija važnih ličnosti s područja religije i

\footnotetext{
${ }^{24}$ Usp. Szentmartoni, Religiozni simboli..., 436.

${ }^{25}$ Usp. J. MOREY, Winnicott's splitting headache considering the gap between Jungian and object relations concept, Journal of Analytical Psychology, 50 (2005) 3, 333-350.

${ }^{26}$ Usp. David TACEY, Jung and New Age, London, Psychology Press, 2001.

${ }^{27} \mathrm{U}$ pismu B. Wilsonu, začetniku Anonimnih alkoholičara Jung će zapisati riječi koje odražavaju duboku potrebu mnogih ovisnika, ne samo alkoholičara: »Njegova žudnja za alkoholom bila je jednaka, na nekoj nižoj razini, duhovnoj žeđi našeg bića za cjelovitošću, srednjovjekovnim jezikom izraženo: sjedinjenjem s Bogom.« Uz riječ »Bog« Jung je dodao riječi Psalma 42: »Kao što košuta žudi za izvor-vodom, tako duša moja čezne, Bože, za tobom « [usp. Antun VOLENIK, Duhovnost Anonimnih alkoholičara i pastoralno savjetovanje, Obnovljeni život, 70 (2015) 1, 55-67].

${ }^{28}$ Autori koji slijede Jungove postavke s kršćanskih polazišta - A. Ulanov i W. Clift - naglašavaju važnost religijskog iskustva i individualizacije kroz povezivanje selfa i Boga i opasnosti gubitka religioznih simbola u modernom društvu (usp. Ann B. ULANOV, Finding Space. Winnicott, God, and Psychic Reality, London, Westminster John Knox Pr, 2001). U tom kontekstu važna je i Jungova korespondencija s dominikancem V. Whitom.

${ }^{29}$ Usp. James NELSON, Psychology, sprituality and religion, Valparaiso, Springer, 2009, 143-174.
} 
duhovnosti, kao što su one o M. Lutheru i M. Gandhiju te osobito Isusu ${ }^{30}$ već i zbog činjenice da u domeni razvojne psihologije daje prvu sveobuhvatnu, cjeloživotnu teoriju razvoja ličnosti baziranu na pitanju identiteta koju utemeljuje na psihosocijalnom, a ne više na psihoseksualnom principu. ${ }^{31}$ Njegov rad, u povezanosti s razvojnim fazama djeteta, do kojih je u svojim istraživanjima došao J. Piaget, vrlo su važni za današnje razumijevanje načina kako se u djetinjstvu i adolescenciji stvaraju predispozicije za religiozno i duhovno u čovjeku i koje su faze toga razvoja. ${ }^{32}$ Razvijanje vrlina vjere i nade, što on smješta u svoju prvu fazu razvoja, kao i pitanje srama i krivnje iz druge i treće faze, samo su neke od važnih poveznica s religioznim razvojem djeteta koja se mogu promatrati i istraživati kroz Eriksonovu psihosocijalnu teoriju ličnosti. Generalno se može reći da Eriksonovo shvaćanje religije uvelike počiva na preedipalnom odnosu majka - dijete te da on zbog toga religiju ne smatra nezrelom, već štoviše, smatra da je prakticiranje religije i duhovnosti u psihološkom smislu zdravo i potrebno za pun razvoj osobne i socijalne zrelosti. U tome je on blizak analitičarima teorije objektnih odnosa i s njima zapravo čini cjelinu.

Ovdje treba spomenuti i američkog isusovca W. Meissnera čiji je gotovo cjelokupan rad bio posvećen utjecaju religijskog iskustva i psihoanalize u kontekstu ego psihologije. Tu se osobito izdvaja njegova psihobiografska studija sv. Ignacija Loyolskog $u$ kojoj pokazuje da je Ignacije uspio religioznom kreativnošću nadići značajne psihopatološke probleme koji su se pokazivali kroz njegovo mladenaštvo, ali ne toliko kao rezultat nekih nadnaravnih transformacija osobnosti, već integracijom onih redovitih, kroz ego snage koje je posjedovao. ${ }^{33}$

Začetnik self psihologije, H. Kohut, kroz ideju razvoja od primitivnog do zrelog narcizma pokazuje da zreli narcizam uključuje prijenos libida sa sebe na samotranscendirajući ideal, a karakteriziraju ga kvalitete, poput kreativnosti, empatičnog razumijevanja, humora i mudrosti. ${ }^{34}$ Iako se Kohut, poput Winnicotta, nije sam izravno bavio religijom, mnogi su kasniji autori slijedili njegove ideje u razumijevanju religije, ${ }^{35}$ pri čemu naglasak nije na zajedništvu

\footnotetext{
${ }^{30}$ Usp. Donald CAPPS, Erik Erikson verbal portrait's Luther, Gandhi, Einstein, Jesus, R\&L, London, 2014, 1-21.

${ }^{31}$ Usp. Erik ERIKSON, Identity. Youth and crisis, New York, Faber and Faber, 1968.

${ }^{32}$ Usp. Hetty ZOCK, A Psychology of Ultimate Concern. Erik H. Erikson's Contribution to the Psychology of Religion, New York, Rodopi, 2004.

${ }^{33}$ Usp. William W. MEISSNER, Ignatius of Loyola. The Psychology of a Saint, New Haven, Yale University Press, 1990.

${ }^{34}$ Usp. Heinz KOHUT, The Analysis of the Self, New York, International Universities Press, 1971.

${ }^{35}$ Spomenimo i Fromma i njegovu knjigu Psihoanaliza i religija u kojem daje umjeren stav prema religiji opisujući ju kroz dječju potrebu da se ostane u sjeni protektivnih figura, ali i kao snagu koju potiče najbolje u čovjeku. Opseg ovoga članka ne dopušta nam lakanovsku psihoanalizu, no spomenimo da je J. Lacan imao puno složeniji pogled na odnos između znanosti, psihoanalize te religije (osobito teologije i njenih jezičnih odrednica) od klasičnog Freudova pristupa (usp. Janet L. JACOBS, Donald CAPPS, Religion, Society, and Psychoanalysis, Oxford, Westview Press, 1997, 218-229).
} 
ili sjedinjenju s numinoznim objektom (Bogom) već u samoostvarenju, osobito kroz ideje self helpa i samo-duhovnosti. ${ }^{36}$

\section{Psihologija objektnih odnosa}

Britanska struja teorije objektnih odnosa (M. Klein, D. Winnicott, J. Bowlby te W. Fairbairn) otvara centralni i najvažniji pravac kojim će psihodinamska teorija integrirati duhovno i religiozno u svoj teoretski koncept i omogućiti razumijevanje i korištenje religioznih fenomena, uvjerenja i vrijednosti u psihoterapiji. Mnogi predstavnici britanske teorije objektnih odnosa imali su ili vjersko podrijetlo ili bili naklonjeni religiji, dijelom i zbog toga što su povijesni $i$ kulturni faktori uzrokovali da se dobar dio britanskog prosvjetiteljstva odvijao unutar kršćanstva, a ne protiv njega. ${ }^{37}$ Svi autori su u svojim istraživanjima bili usmjereni na najraniji period djetetova života s fokusom na karakteristike dijadnog odnosa majke i djeteta, odnosno kvalitete procesa djetetova psihičkog oblikovanja. To vrijedi i za začetnicu ovog pravca, M. Klein, koja počinje shvaćati ulogu majke kao parcijalnog (dobra i loša dojka) i cjelovitog objekta te tako postupno daje temelje teoriji objektnih odnosa.

Ipak, a da joj je to nije bila nakana, ona čini nešto jednako značajno za razumijevanje stvaranje religijske slike u psihodinamskoj teoriji. Dok Freud cjelinu religijskih fenomena sa Bogom Ocem kao ključem tumači iz edipalnog kompleksa i time zatvara vrata svakom pozitivnom tumačenju i korištenju religijskih fenomena i vrijednosti u smislu mentalne ravnoteže i zdravlja, Klein i njezini sljedbenici poći će zapravo drugim putem. Ona će otvoriti put shvaćanju libidinoznog preedipanog odnosa s primarnim roditeljem, a to je tada majka, te samom sebi u stadiju primarnog narcizma, povezujući cijeli jedan svijet religioznog pod vidikom fantazmatskog i objektno-majčinskog. Time ona ne samo da otvara put puno cjelovitijeg shvaćanja slike Boga izvan strogo transferne slike vlastitog oca i širi ga na puno libidonizniju sliku majke već putem odnosa s objektom utire put razumijevanja fantazmatskog u objektu koji je ključan za razumijevanje ranih faza osnova za religiozno. ${ }^{38}$

\subsection{Winnicottov prijelazni proces te istinski i lažni ja}

Winnicott je rastao u religioznoj obitelji, a u psihoanalizu ga je uveo O. Pfister. Iako sam ne govori puno o svojoj vlastitoj vjeri, Winnicott je cijelog

\footnotetext{
${ }^{36}$ Usp. Daniel M. WULFF, Psychology of Religion Classic and Contemporary, New York, J. Siley and Sons, 1991, 355-356.

${ }^{37}$ Usp. Fraser WATTS, Theology and psychology, Aldershot, Ashgate, 2002.

${ }^{38}$ Usp. Daniel M. WULFF, Psychology of Religion Classic and Contemporary, New York - Toronto, John Siley and Sons, 1991, 339-341.
} 
svog života zadržao dozu religioznosti i teizma, što je vidljivo u drugom dijelu njegova života. Koristeći razumljive pojmove, uveo je termine i fraze koji su danas nezaobilazni, poput »dovoljno dobra majka«, »istinski i lažni self«, »podržavajuće okruženje«, "prijelazni objekt i prijelazni fenomeni« i »ne postoji ono što se naziva beba«.

Prema Winnicottu, istinsko ja počinje se oblikovati kada dojenče počinje doživljavati kontinuitet svoga bića i omnipotencije u primarnom narcizmu dovoljno dobra majka. Izvor istinskog ja jest kreativnost koju dojenče razvija kroz rana opetovana iskustva da je on ili ona (sve)moćan i da može više puta stvarati predmete svoje želje (»kontrola majke« kao objekta koji se pojavljuje kada on/ona želi). Ovo stvaranje i rekreiranje postaje osnova djetetove sposobnosti da bude kreativan i prihvati život kao igru, a nužno je u uspostavljanju odnosa s drugima, u razvijanju sposobnosti brige za druge za razvoj kulture te konačno religioznosti. ${ }^{39} \mathrm{~S}$ druge strane, Winnicott je tvrdio da će se pojedinac čija je kreativna sposobnost bila inhibirana teško osjećati uistinu živim, a kasnije u životu može imati poteškoća u prihvaćanju da je život vrijedan življenja. ${ }^{40}$ Tu se dio dojenčetova ja odvaja i postaje lažno ja. Prema Winnicottu, postoje različite razine lažnog $j a$, no ovdje je važno naglasiti da su koncept stvarnog i lažnog ja koristili brojni kršćanski autori (Benner, Eldredge, Finley, Manning, Merton) jer jako dobro odražava koncept autentičnog življenja ljudskih i kršćanskih vrijednosti. ${ }^{41}$

Jedna od važnih primjena Winnicottovih stavova o prijelaznim objektima, prijelaznim pojavama i međuprostoru, doživljavanja koja on naziva "prijelazni proces«, jest $\mathrm{u}$ razumijevanju religije i kulture. Prijelazni proces nije potpuno unutrašnji i imaginativni niti je posve vanjski i stvaran. Ovdje je tipičan izbor djetetova prijelaznog objekta, kao što su medvjedić, neka druga igračka ili dekica, koji pomažu u prijelazu od djetetove fantazije o omnipoteniciji (kontroliranju vanjskog objekta - majke) k prihvaćanju objektivne stvarnosti. ${ }^{42}$ Taj prijelazni proces bitno je obilježen fantazijom, ali je ona ovdje shvaćena pozitivno, kao nešto potrebno i važno u razvitku zdravog i kreativnog odnosa sa svijetom. Tako ova faza, po Winnicottu, daje osnovnu bazu za kulturni i religiozni kasniji razvoj čovjeka. ${ }^{43}$

\footnotetext{
${ }^{39}$ Usp. Daniel W. WINNICOTT, The maturational processes and the facilitating environment. Studies in the theory of emotional development, Madison, International Universities Press, 1996.

${ }^{40}$ Usp. Daniel W. WINNICOTT, Playing and reality, New York, Brunner-Routledge, 1971/2005.

${ }^{41}$ Usp. Steven PARKER, Eduard DAVIS, The False Self in Christian Contexts: A Winnicottian Perspective, Journal of Psychology and Christianity, 28 (2009) 4, 110-132.

${ }^{42}$ Usp. Winnicott je primijetio da dijete prijelazni objekt približava svome licu u vremenu prije spavanja ili u trenutku neke krize ili nelagode.

${ }^{43}$ Usp. Daniel W. WINNICOTT, Transitional objects and transitional phenomena. A study of the first not-me possession, The International Journal of Psycho-analysis, 34 (1953) 2, 89-97.
} 
Aplikacije ovih Winnicottovih ideja temeljenih na Kleinovim zapažanjima o vanjskom objektu, dobroj i lošoj dojci, autističnoj i shizoidno-paranoidnoj poziciji novorođenčeta uistinu su brojna. Za nas su najvažnija ona koja žele pokazati da se svijest o sebi, taj najvažniji pokazatelj ljudske osobnosti i čovjeka samog, po teoriji objektnih odnosa razvija iz stvaranja slike o vanjskom objektu i tranzitivnog procesa prema realnim objektima i realnom svijetu, gdje je djetetu potreban prijelazni objekt da bi ga umirio i dao mu sigurnost. Iz toga mnogi autori dalje grade teoriju o kulturi i religiji kao ultimativnim vanjskim objektima, nužnim za istinsku psihološku maturaciju čovjeka. ${ }^{44}$ Autori koji su nastavili razvijati ovaj dio Winnicottove teorije (P. Pruyser, ${ }^{45}$ W. W. Meissner i A.-M. Rizzuto) uvelike su ju proširili i dali joj značenje koje nadilazi Winnicottova polazišta budući da on još uvijek gleda na psihološke korijene religije kao, istina pozitivne, ali ipak utemeljene na iluziji.

\subsection{Ana-Maria Rizzuto i slike o Bogu}

Ponešto drugačijim putem pošla je argentinsko-američka psihijatrica i psihologinja A.-M. Rizzuto usmjerivši svoje istraživanje na onaj dio religioznosti koji dijele podjednako istočne i zapadne religije, a to su slike o Bogu. U svojim istraživanjima, također pod Winnicottovim utjecajem, pošla je od ideje da te unutrašnje slike i reprezentacije Boga imaju svoje korijene u ranim objektnim odnosima pojedine osobe.

Njezini zaključci proizlaze iz kliničkog rada i studija slučaja 20 pacijenata/ klijenata kršćanske i židovske denominacije. U svojim istraživanjima ona je primjenjivala upitnike, nestrukturirane intervjue te osobito crteže koje su oni sami stvarali na temu svojih vlastitih obitelji i slika Boga. Na osnovu svega toga Rizzuto je zaključila da ni u jednom slučaju nije došlo do stvaranja slike o Bogu koja bi nastala isključivo iz unutrašnje slike (imago) jednog ili drugog roditelja. ${ }^{46}$ Iako je njezin rad psihoanalitički establišment često kritizirao i odbacivao zbog prevelike ovisnosti o studijama slučaja koji nisu dovoljno dobro klinički

\footnotetext{
${ }^{44}$ Usp. Volney P. GAY, Winnicott's Contribution to Religious Studies, Journal of the American Academy of Religion, 51 (1985) 3, 371-395.

${ }^{45}$ Proširio je Winnicottovu ideju o unutrašnjem svijetu autističnih fantazija i vanjskom realističnom svijetu uvodeći treći, iluzionistički utemeljen na igri i kreativnoj imaginaciji u kojoj osjećaji nisu suprotni mišljenju, u kojemu se ostvaruju darovi i talenti i u kojem princip užitka nije u kategorijalnoj suprotnosti s principom realiteta. »Transcendentno, sveto i mistično ne mogu biti prepoznati u vanjskom svijetu kroz čisto realistično gledanje i slušanje niti se one pojavljuju direktno iz uma kao fikcije ugode. One se pojavljuju u intermedijalnoj zoni realnosti koja je također intermedijalna ljudska aktivnosti - niti posve subjektivna niti posve objektivna « (Paul W. PRUYSER, The Minister as Diagnostician. Personal Problems in Pastoral Perspective, Philadelphia, Westminster Press, 1976, 56).

${ }^{46}$ Usp. Ana-Maria RIZZUTO, The birth of the living God. A psychoanalytic study, Chicago, The University of Chicago Press, 1979.
} 
utemeljene, ${ }^{47}$ ipak je njezin utjecaj velik, kako među kliničarima tako i među kasnijim istraživačima i teoretičarima. ${ }^{48}$

Polazeći od dvaju polazišta, naime od slike Boga kako se ta teorija razvijala u psihodinamskoj tradiciji (npr. Erikson i Jung) ${ }^{49}$ te od Winicottovih zaključaka o iluzionističkom prijelaznom objektu, ona pokazuje da se slika Boga podjednako stvara od stvarnih roditelja, od idealiziranih slika roditelja (primarni narcizam i omnipotencija) te od straha od roditelja i ranih važnih figura u dječjoj imaginaciji ili stvarnosti. Iako priznaje važnost edipalnog stadija, Rizzuto pokazuje da se slika Boga rađa, razvija i transformira kroz sve faze razvoja osobe od najranijih stadija razvoja preko adolescencije pa sve do zadnjih faza života po principu Boga kao prijelaznog objekta.

»Svaka nova faza u ciklusu identiteta«, uključujući i onu posljednju - starenja i umiranja, »donosi sa sobom i specifičnu religioznu krizu $\aleph^{50} \mathrm{i}$, istovremeno, izazov stvaranja nove, primjerenije slike Boga. Ipak, često se događa da slika Boga ostaje nepromijenjena i tako ona s vremenom može postati anakrona i irelevantna. Kao prijelazni objekt, tada Bog

»dijeli nepredvidivi život plišanca/medvjedića maloga djeteta: kada je potreban on se žurno pokupi s mjesta gdje obično leži, biva grljen ili maltretiran, a kada se unutarnja oluja smiri ponovo ostaje zanemaren i ostavljen tamo gdje obično leži. Tamo ostaje, pružajući tihu i šutljivu podršku svoje gotovo neprimjetne prisutnosti. « ${ }^{51}$

Rizzuto je u svom istraživanju došla do nekoliko važnih zaključaka koji se mogu sumirati u tri najvažnija. Prvo, da svi ljudi rođeni i odgojeni u zapadnom kulturnom krugu imaju neku sliku o Bogu ili unutrašnji radni model Boga uz mogući teoretski koncept ili intelektualno znanje o Bogu, ali to ne mora značiti da nužno prepoznaju i priznaju njegovo postojanje. Nadalje, elementi za stvaranje takve slike o Bogu uzimaju se iz ranih objektnih reprezentacija i interakcija koje ravnopravno uključuju očinsku i majčinsku stranu. Štoviše, njena

\footnotetext{
${ }^{47}$ Usp. Michel ST. CLAIR, Human relationships and the experience of God: Object relations and religion, New York, Paulist Press, 1994, 45.

${ }^{48}$ John McDARGH, Creating a new research paradigm for the psychoanalytic study of religion. The pioneering work of Ana-Maria Rizzuto, u: Daniel J. JACOBS i dr. (ur.), Religion, society, ety, and psychoanalysis. Readings in contemporary theory, Boulder, Westview Press, 1997, 181-199.

${ }^{49}$ E. Eriksonu se bavio ovom idejom i razradio ju kroz tri vrste slike o Bogu: prva koja traži ljubav i prihvaćanje kroz materijalne dokaze, druga koja se može poistovjetiti sa savješću i povezana je s očinskom slikom boga i konačno treća koja bi bila pred- ili nadroditeljska slika Boga, gdje je »Bog čistina ničega«. Jung je s druge strane, stava da je slika Boga arhetipna, pa su tako specifične karakteristike Boga koju ima neka osoba manje važne u usporedbi s njenim univerzalnim karakteristikama.

${ }^{50}$ Ana-Maria RIZZUTO, The birth of the living God: A psychoanalytic study, Chicago, The University sity of Chicago Press, 1979, 89.

${ }^{51}$ Citirano prema: Daniel M. WULFF, Psychology of Religion Classic and Contemporary, New York - Toronto, John Siley and Sons, 1991, 398.
} 
istraživanja pokazuju da osobe s pretežno dobrodušnom slikom Boga pokazuju tendenciju stvaranja takve slike iz odnosa s majkom, dok oni sa nesigurnim slikama ispunjenim strahom imaju tendenciju takve slike graditi iz odnosa s ocem. Također primjećuje da se slika o Bogu nadograđuje reprezentacijama Boga kakvim ga nude etablirane religije kao i kasnijim osobnim iskustvom. Konačno, ona je, na osnovu svojih istraživanja stvorila svojevrsnu tipologiju slika o Bogu i pripadajućeg religioznog ponašanja u skladu s određenom slikom. To su: a) oni koji su svjesni Boga, b) ispituju Božju prisutnost, c) nisu za to zainteresirani i iznenađeni su time da drugi jesu, d) doživljavaju Boga kao vrlo zahtjevnog te bi ga željeli eliminirati. ${ }^{52}$ Do sličnih rezultata došao je Banschick radeći s grupom adolescenata uz napomenu da je on našao i petu vrstu slike o Bogu, gdje je on viđen kao neosobna snaga. ${ }^{53}$

\section{Zaključak}

Psihodinamska teoretska paradigma ima više od stoljeća dugu povijest istraživanja i stvaranja teoretskih koncepata (bazirana uglavnom na studijama slučaja, ali se sve više otvara i kvantitativnim istraživanjima) te je u svim svojim školama i pravcima pokazivala interes za duhovno i religiozno. Upravo zato ona je nezaobilazna u proučavanju psihologije religije, osobito na teološkim i/ili katehetskim učilištima kao nezaobilazan dio pastoralne psihologije koja joj može i treba dati na važnosti. Takva istraživanja, kao i kod mnogih drugih škola i terapeutskih pravca, upućuju da se na ovom području treba okrenuti ne samo dijalogu i korištenju drugih teoretskih postavki unutar dubinske psihologije, prije svega onih iz jungovske analitičke psihologije te novijih teoretskih koncepata, nego i onima iz egzistencijalističke i humanističke, gdje se osobito izdvaja Franklova logoterapija.

Zato bismo ovaj zaključak završili citirajući sigurno najvećeg poznavatelja Junga na našim prostorima, dugogodišnjeg profesora pastoralne medicine na Teološkom fakultetu u Beogradu, V. Jerotića koji je već davno vidio potrebu otvaranje psihoterapije religioznom i duhovnom:

»Otud nije nikakvo čudo što psihijatar u Evropi i Americi, poslednjih tridesetak godina, sve više potiskuje i zamenjuje ispovednika. Protestantizam, koji je najmanje razvio praksu ispovedništva, prvi je morao da popusti i priznade moć psihoterapeuta, posebno kada je reč o neurotičnim pacijentima sa religioznom problematikom. Tako danas imamo paradoksnu situaciju da sami protestantski teolozi šalju svoje vernike, sa kojima ne znaju kako da izađu na kraj, psihoanali-

\footnotetext{
${ }^{52}$ Ana-Maria RIZZUTO, Object relations and the formation of the image of God. British Journal of Medical Psychology, 47 (1974) 83-99.

${ }^{53}$ Mark BANSCHICK, God-representations in adolescence, u: Mark FINN, Object relations theory and religion, Westport, Praeger, 1992, 73-85
} 
tičarima. Katoličanstvo je mnogo duže pružalo otpor takvom razvoju događaja, ne samo zato što je od početka imalo sumnjičav stav prema psihoanalizi, kao trojanskom konju savremenog života, već i zbog toga što su egzercicije Ignjacijusa Lojole sadržavale puno vrednih, čak i za analitičare interesantnih psiholoških tananosti ljudske duše. Pri svemu tome danas više ne iznenađuje bliska saradnja katoličkih teologa sa psihoanalitičarima, niti je retkost da se neki visoko školovani jezuita sam podvrgne didaktičkoj analizi. « ${ }^{54}$

Antun Volenik**: - Irma Džambo***

Object Relations Theory and its Implication in the Pastoral Psychology and the Psychology of Religion

Summary

The paper shows the resultants of the research of the relationship between theory of object relations as a part of psychoanalytic and psychodynamic psychology and religion and spirituality in a broader sense. It also seeks to show the turn in the valorisation of religion and spirituality that the theory of object relations, and in particular Winicott's theory of the true and false self and the transitional object, brought in the psychodynamic paradigm. The paper presents Freud's, Jung's and Adler's works in psychology of religion and spirituality. Key words: psychoanalytic and psychodynamic psychology, psychodynamic psychotherapy and religiosity / spirituality, psychology of religion.

(na engl. prev. Antun Volenik)

\footnotetext{
${ }^{54}$ Vladeta JEROTIĆ, Sabrana dela. Psihoanaliza i kultura, Zadužbina V. Jerotića - Ars libri, Beograd 1969/2007, 79. Ovo je najbolje potvrdio papa Franjo kada govori o svojoj šestomjesečnoj analitičkoj psihoterapiji koju je, kao svećenik obavio u rodnoj Argentini. U duhu suradnje psihoanalize i kršćanstva jednako je zanimljivo njegovo svjedočenje da je njegova psihoanalitičarka pred kraj svoga života imala potrebu razgovarati s njim kao svećenikom (usp. Franjo, Politika i društvo. Razgovori s Dominiqueom Woltonom, Split, Verbum, 2019).

* Antun Volenik, PhD, Assoc. Prof., University of Zagreb, Faculty of philosophy and religious studies; Address: Jordanovac 110, HR-10000 Zagreb, Croatia; E-mail: a.volenik@ffrz.hr.

**: Irma Džambo, PhD, Assoc. Prof., JU Dom zdravlja Kantona; Address: Sarajevo, Igmanska 52, BiH-71101 Sarajevo, Bosnia and Herzegovina; E-mail: irmadzambo@yahoo.com.
} 